International Journal of Engineering \& Technology, $7(4.20)(2018)$ 185-189
International Journal of Engineering \& Technology
SPC
Website: www.sciencepubco.com/index.php/IJET
Research paper

\title{
Experimental Study for Ability to Use Plaster of Pairs Instead of Normal Concrete
}

\author{
Hashim Tariq Hashim ${ }^{1 *}$, Dr. Mohammed Mosleh Salman² \\ ${ }^{I}$ M.Sc. student, Civil Engineering Department, Al-Mustansiriayah University, Baghdad, Iraq \\ ${ }^{2}$ Prof. Dr., Civil Engineering Department, Al-Mustansiriayah University, Baghdad, Iraq. \\ *Corresponding author E-mail: hashimtariq95@gmail.com
}

\begin{abstract}
This research investigated the possibility of using plaster of Paris instead of cement in some internal structural parts and non-exposed to moisture by casting (nine) samples divided in three group. First group was normal concrete, second was plaster of pairs concrete group and finally plaster of Paris with aggregate concrete. All of them have the same dimension $(1000 \times 150 \times 200) \mathrm{mm}$ and the same reinforcement ratio. Group one was cured with water while the rest were isolated in a place far away from the moisture. All sample designed to be failed in flexural. The process of testing was divided in two methods; for properties of material used as explain above and for samples tested under two-point load at several curing time (7,28 and 90) days. Each period consists of three samples one from each group. The result showed that the third group (plaster of Paris with aggregate concrete) approximately closer to normal concrete in applying a load by the ratio of (98\%) in 7 days, (87\%) in 28 days and (94\%) in 90 days. While the second group (plaster of pairs concrete) was acceptable when compared with normal concrete because of missing aggregate.
\end{abstract}

Keywords normal concrete, plaster of pairs, aggregate, reinforcement ratio, curing, and moisture.

\section{Introduction}

Mesopotamia is the oldest in using plaster rocks and its product. Throughout the ages, with evidence of characterization of the successive civilizations, as research and studies conducted in archaeological sites are shown the best selection of materials and the most appropriate to the environment, Through the physical residues of archaeological and heritage materials since the start of rural settlements and the emergence of buildings with distinctive architectural features and distinct. Plaster is an important material as it is used as a whitish material in construction, joining the bricks, also used in (mortar, arches, domes, bonding materials, whiteness, decoration and light blocks). Plaster properties can be improved by adding some materials like tar, fiber plants, cement etc.

Plaster has been used since ancient times for many purposes, in recent decades, production has doubled globally by building factories, improving their productivity, and developing new and more sophisticated products [1]. The most important of these products can be presented as follows:

- Reinforced plaster panels as internal partitions (reducing dead loads of construction parts in multi-story buildings and consequent lower cost of foundations) and plaster panels for secondary ceilings [1].

- Fireproof plaster plates to prevent the rapid transition of heat to other parts of origin with same times safely and without damage, the plaster works naturally as a fire-resistant spraying system because the plaster contains about $21 \%$ of the water united within the crystalline structure, so delays heat transfer [2].

- Sound-proof plastered panels with plant materials with cellulose fibers such as wood saw reeds, glass fibers or mineral wool with porous or decorative facets and the resulting face with high sound absorption [3].
- Plaster blocks of different types (normal, lightweight, armed with agricultural waste, improved with Nora and additives to improve products using glue and others) [4].

- Concrete plaster (in different sizes) mixed with sand, sand and Nora, rubble (brick breaker), rubble (waste and debris of buildings) [5].

- Load and Non-load bearing walls (precast, casting site) [5].

- Exterior walls (tiling, plates, scattering) [5].

\subsection{The research aim}

The objective of this study is to investigate the flexural behavior (in terms of first crack load (Pcr), ultimate flexural strength $(\mathrm{Pu})$, ultimate deflection $(\Delta \mathrm{u})$ and load-deflection behavior) of simply supported singly reinforced beam having dimensions of $(1000 \times 150 \times 200) \mathrm{mm}$ under symmetrical two points loads, and the other main objective of this study is the focus on the influence of concrete constituents on the materials properties of all type concrete are used in this study.

Most of the previous researchers were partially replace Portland cement in construction products while the purpose of this research is to study the possibility of using plaster instead of concrete in some internal structural parts and non-exposed to moisture.

\section{Methodology}

All sample design to be the Failure as a flexural failure and the design load is $(80 \mathrm{kN})$ according to (ACI-318-14) [6]. as shown in (Fig 1) 


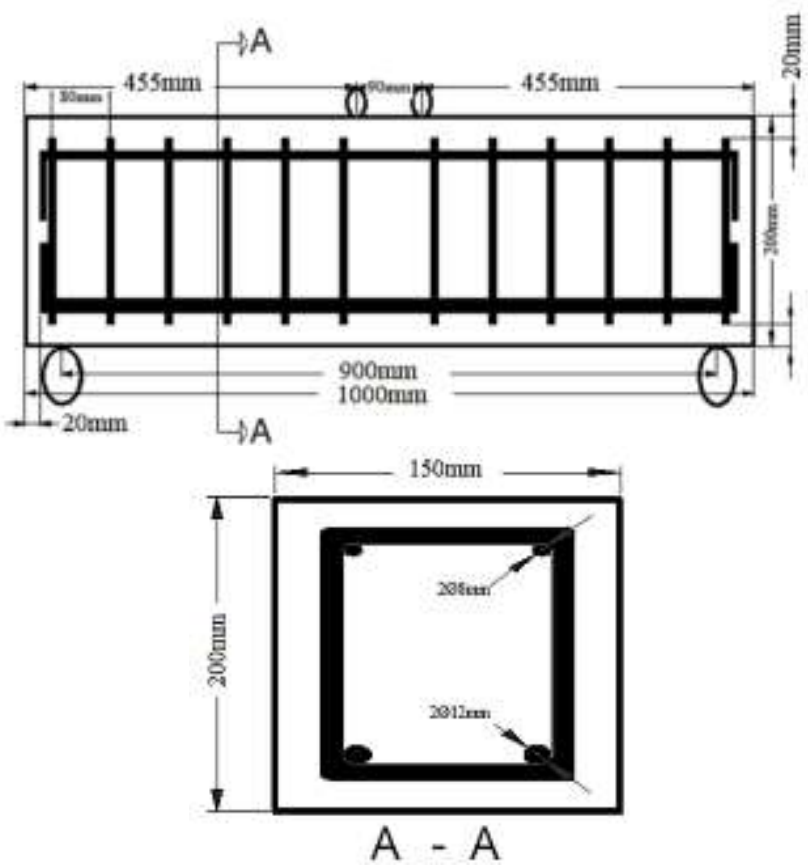

Fig. 1: Steel Reinforcement details

The Properties of Material that Used

Table 1: Chemical Composition of cement

\begin{tabular}{|c|c|c|c|}
\hline Cocpostion & Abreenition & Curat by vaigt(a) & 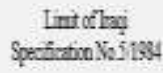 \\
\hline line & 680 & 6.11 & - \\
\hline Süna & 5.0 & 2037 &. \\
\hline Alema & $\mathrm{AlO}$ & 515 & - \\
\hline Irocoude & $\mathrm{F}=0$ & 439 & - \\
\hline Megnesi & $\mathrm{MgO}$ & 161 & $50(\mathrm{mar})$ \\
\hline Sulft: & 50 & 257 & $23(\mathrm{man})$ \\
\hline Ioss aigution & $\mathrm{LOI}$ & 272 & $40(\cos )$ \\
\hline houble & [R. & 0.5 & $15(\mathrm{man})$ \\
\hline \multirow[t]{2}{*}{ Lime strotinfacts } & LSE. & 032 & (0.56-102) \\
\hline & \multicolumn{2}{|c|}{ UEn corpourds (Bgges aquation) } & \\
\hline Trodun Sticate & CS & 492 & . \\
\hline Dialcimsüra: & CS & 2150 &. \\
\hline Tnakim Almingt: & $C A$ & 622 & - \\
\hline 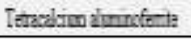 & CaF & 133 & - \\
\hline
\end{tabular}

Table 2: Physical Properties of Cement

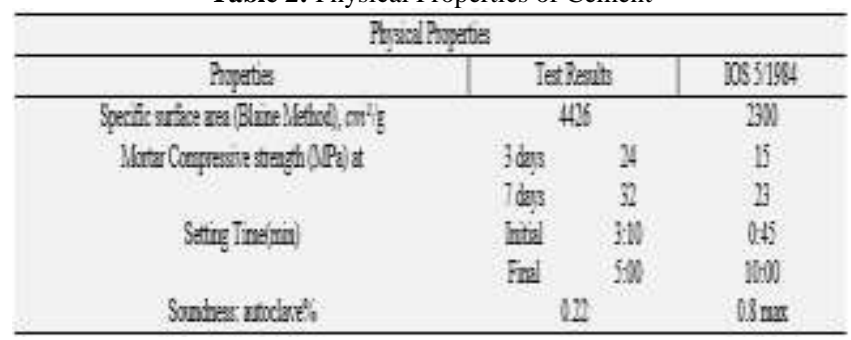

Table 3: Chemical Composition of Plaster of Paris

\begin{tabular}{|c|c|c|}
\hline Crepooat & TestResils/4 & The Inits of Sadard. W. Wh \\
\hline Free water & 015 & \\
\hline Carbarese & 27 & $9(\max )$ \\
\hline LO.1 & & $9(\max )$ \\
\hline $\mathrm{SO}_{2}$ & 0.4 & \\
\hline $\mathrm{ALO}_{1}$ & 051 & \\
\hline $\mathrm{F}=\mathrm{O}_{1}$ & $\mathrm{~N}$ & \\
\hline 90 & $56 \%$ & 4) (rin) \\
\hline 0.20 & 3921 & 23 from 90 \\
\hline $\mathrm{M}=0$ & $\mathrm{~K}$ & $026(\mathrm{mat})$ \\
\hline Total & 99,9 & \\
\hline
\end{tabular}

Table 4: Physical Properties of Plaster of Paris

\begin{tabular}{|c|c|c|}
\hline \multicolumn{3}{|c|}{ ProvelPoperts } \\
\hline Propates & Testrects & 2035134 \\
\hline 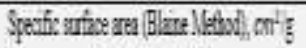 & Ho & LAK \\
\hline Stting Irve(nin) & y & 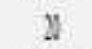 \\
\hline 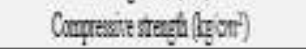 & 113 & 4 (III) \\
\hline
\end{tabular}

Table 5: Grading of Fine Aggregate

\begin{tabular}{|c|c|c|}
\hline Serenge( $(x)$ & Whang briati & 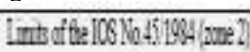 \\
\hline 10 & 10 & 100 \\
\hline 475 & MiIj & QN110 \\
\hline 236 & 78 & 71010 \\
\hline 111 & 681 & 55.91 \\
\hline 061 & 4351 & 35.9 \\
\hline (3) & 146 & 830 \\
\hline 015 & 0.2 & Q10 \\
\hline
\end{tabular}

Table 6: Physical Properties of Fine Aggregate

\begin{tabular}{|c|c|c|}
\hline Puracal Procetes & TetPests & 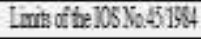 \\
\hline Spectignty & 253 & - \\
\hline Siffectedert & $300 \%$ & $\leq 0$ ish \\
\hline Abountoon & 225 & - \\
\hline
\end{tabular}

Table 7: Grading of Coarse Aggregate

\begin{tabular}{c|c|c}
\hline Sieve size (mm) & \%Passing by weight & $\begin{array}{c}\text { Limits of the Iraqi Specification } \\
\text { No.45/1984 }\end{array}$ \\
\hline 20 & 100 & 100 \\
14 & 100 & $90-100$ \\
10 & 74.5 & $50-85$ \\
5 & 3.5 & $0-10$ \\
\hline
\end{tabular}

Table 8: Physical Properties of Coarse Aggregate

\begin{tabular}{|c|c|c|}
\hline Plysical properties & Jet Result & Limits of lnsil Specification Xo.45 198 \\
\hline Specific g्रायो & 260 & - \\
\hline Sulbste ourtent & $0.06 \%$ & $0.1 \%$ (max) \\
\hline Abscoptom & $0.73 \%$ & - \\
\hline
\end{tabular}

The mix proportion for (Normal Concrete) is designed according to ACI recommended practice ACI 211.1-91[7]. The target compressive strength is (25MPa). Groups one consists of (N.C.) and material proportions which are 1:1.33:2.89 water/cement $=0.44$ (this ratio has been taken after several experimental mixtures) by weight, as shown in the (Table 9) below

Table 9: Mix Proportions for Normal Concrete Strength

\begin{tabular}{c|c|c|c|c}
\hline Groups & $\begin{array}{c}\text { Cement } \\
\left(\mathrm{kg} / \mathrm{m}^{3}\right)\end{array}$ & $\begin{array}{c}\text { Sand } \\
\left(\mathrm{kg} / \mathrm{m}^{3}\right)\end{array}$ & $\begin{array}{c}\text { Gravel } \\
\left(\mathrm{kg} / \mathrm{m}^{3}\right)\end{array}$ & $\begin{array}{c}\text { Water (Lit- } \\
\left.\text { ter } / \mathrm{m}^{3}\right)\end{array}$ \\
\hline One & 415 & 552 & 1200 & 183 \\
\hline
\end{tabular}

Then two group mixtures are used in Plaster of Paris concrete. The first mix is Plaster of Paris only with (water/powder $=0.45$ ) by weight, this mix used for the first group. The second is Plaster of Paris with Coarse Aggregate (0.5) and (water/powder $=0.45$ ) by weight, designed according to (ASTM C 317/C 317M - 00 and C $956-04)$ recommended the practice, used for group two, as shown in the (Table.10) below, all this mixture where be obtained from several laboratory mixture:

\begin{tabular}{c|c|c|c}
\multicolumn{4}{c}{ Table 10: Plaster of Paris Concrete Proportion Mixture } \\
\hline Groups & $\begin{array}{c}\text { Plaster of Paris } \\
\left(\mathrm{kg} / 0.09 \mathrm{~m}^{3}\right)^{*}\end{array}$ & $\begin{array}{c}\text { Gravel } \\
\left(\mathrm{kg} / 0.09 \mathrm{~m}^{3}\right)^{*}\end{array}$ & $\begin{array}{c}\text { Water }(\mathrm{Lit}- \\
\left.\text { ter/0.09 } \mathrm{m}^{3}\right)^{*}\end{array}$ \\
\hline Two & 180 & 0 & 85
\end{tabular}


Three

180

90

85

$*$. These quantities are equal multiply $(3 \times 0.2 \times 0.15 \times 1) \mathrm{m}$.

Nine structural specimens (reduced-scale) beam (sometimes called replica models) are prepared for experimental work purposes These specimens are divided into three groups, each group consists of three beams of dimensions $(1000 \times 150 \times 200) \mathrm{mm}$ as shown in (Table.11) with all details:

\begin{tabular}{|c|c|c|c|c|}
\hline $\begin{array}{l}\text { Type of } \\
\text { Material }\end{array}$ & Group no. & $\begin{array}{l}\text { Beam } \\
\text { Name }\end{array}$ & $\begin{array}{l}\text { Aggregate } \\
\text { ratio } \% *\end{array}$ & $\begin{array}{c}\text { curing } \\
\text { times } \\
\text { (Days) }\end{array}$ \\
\hline \multirow{4}{*}{$\begin{array}{l}\text { Ordinary } \\
\text { Concrete }\end{array}$} & \multirow{3}{*}{ Group One } & $\mathrm{BC} 1$ & 2.89 & 7 \\
\hline & & $\mathrm{BC} 2$ & 2.89 & 28 \\
\hline & & $\mathrm{BC} 3$ & 2.89 & 90 \\
\hline & \multirow{4}{*}{ Group Two } & BP1 & 0.0 & 7 \\
\hline \multirow{3}{*}{$\begin{array}{c}\text { Plaster of } \\
\text { Paris }\end{array}$} & & BP2 & 0.0 & 28 \\
\hline & & BP3 & 0.0 & 90 \\
\hline & & BP1. A & 0.5 & 7 \\
\hline \multirow{2}{*}{$\begin{array}{l}\text { Plaster of } \\
\text { Paris con- } \\
\text { crete }\end{array}$} & \multirow{2}{*}{$\begin{array}{l}\text { Group } \\
\text { Three }\end{array}$} & BP2. A & 0.5 & 28 \\
\hline & & BP3. A & 0.5 & 90 \\
\hline
\end{tabular}

*. These quantities are ratio from cement and Plaster of Paris.

The mold used in casting the samples of research made of ply-wood lubricated with special oil to resist moisture and joint with a screw to facilitate process removal of samples as shown in (Fig. 2)

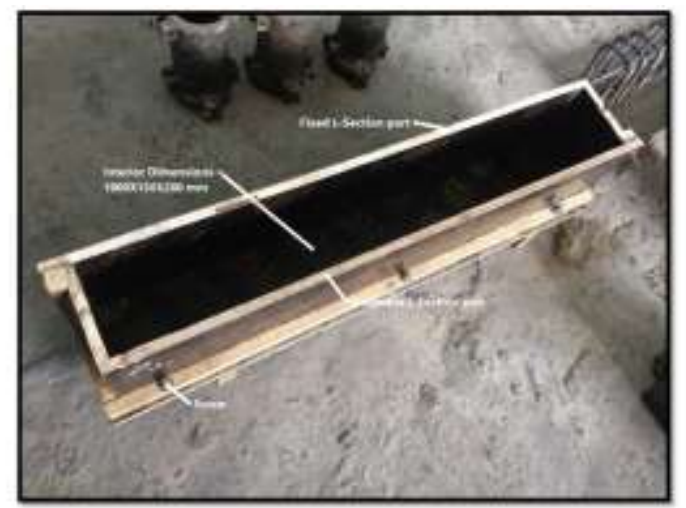

Fig. 2: The Mold used in research

After extruding from the mold the groups, one was curing with water while the rest were isolated in a place far away from the moisture for interval time (7, 28 and 90) days as shown in (Fig. 3)
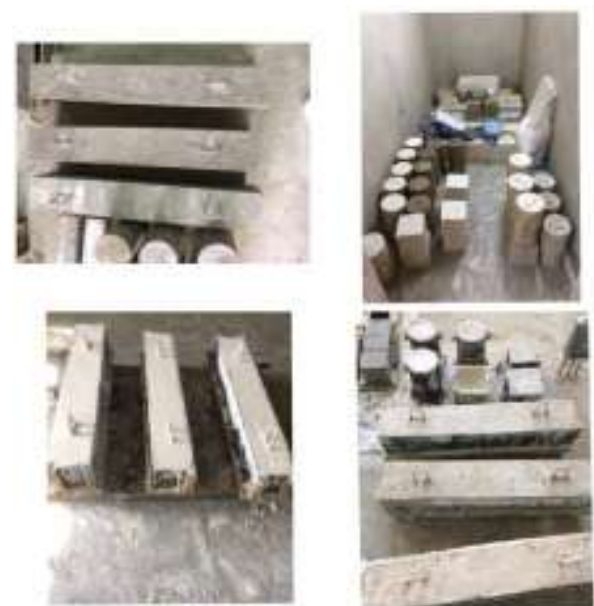

Fig. 3: The samples in the stage of curing

\section{Result and Discussion}

The properties of the material have been computed according to a standard that showed in the (Table.12), same mechanical properties of hardened concrete that examined its self-applied at Plaster of Pairs to be easy compare between them

Table 12: Standard Used in Test

\begin{tabular}{|c|c|c|c|}
\hline \multicolumn{3}{|c|}{ Table 12: Standard Used in Test } \\
\hline & $\begin{array}{c}\text { Number } \\
\text { of } \\
\text { specimens }\end{array}$ & Test & $\begin{array}{c}\text { Standards } \\
\text { of test }\end{array}$ \\
\hline & 3 & $\begin{array}{c}\text { Cube } \\
\text { Compression } \\
\text { Strength }\end{array}$ & $\begin{array}{c}\text { B.S: 1881: } \\
\text { part 116 }\end{array}$ \\
\hline
\end{tabular}

The compressive strength result obtains in two standards (cube and cylinder) showed that cylinder samples give the best result because of uniformly distribution of stress cross-section area and amount of $\left(F^{\prime} c\right)$ are being certified in design. Plaster with two states (with and without aggregate) Give good results and asymptotic to the normal concrete, because of a manufacturing method that used to produce plaster of Paris depend on, the degree of smoothing, burning temperature with another controlled factor process. That was clearly shown in the (Table.13)

Table 13: Material Test Result in (28 Days)

\begin{tabular}{|c|c|c|c|c|}
\hline Material & $\begin{array}{c}\text { Cube } \\
\text { Strength } \\
\left(\mathrm{f}_{\mathrm{cu}}\right) \mathrm{MPa}\end{array}$ & $\begin{array}{l}\text { Cylinder } \\
\text { Strength (f } \\
\text { 'c) } \mathrm{MPa}\end{array}$ & $\begin{array}{l}\text { Splitting } \\
\text { Tensile } \\
\text { Strength } \mathrm{f}_{\mathrm{ct}} \\
(\mathrm{MPa})\end{array}$ & $\begin{array}{l}\text { Modulus of } \\
\text { Rupture } \mathrm{f}_{\mathrm{r}} \\
\text { (MPa) }\end{array}$ \\
\hline $\begin{array}{c}\text { Normal } \\
\text { Concrete }\end{array}$ & 30 & 26.6 & 2.6 & 2.3 \\
\hline $\begin{array}{l}\text { Plaster of } \\
\text { Paris con- } \\
\text { crete }\end{array}$ & 23 & 20.6 & 1.6 & 1.73 \\
\hline $\begin{array}{l}\text { Plaster of } \\
\text { Paris con- } \\
\text { crete with } \\
\text { aggregate }\end{array}$ & 26 & 22 & 2.1 & 2.05 \\
\hline
\end{tabular}

*. Both plasters of Paris and normal concrete have the same standard used in the test in (table.12).

The samples start failure (first crack) at load (from 8 to 27.5) $\mathrm{kN}$, the less amount is (BP1) while the greatest (BP3, BC1) in spite of the (BP3) was without aggregate. But samples with aggregate give the highest value and asymptotic to the normal concrete in ultimate load this can be seen in the (Table.14)

Table 14: The Result of Two-Point Load Test

\begin{tabular}{c|c|c|c|c}
\hline $\begin{array}{c}\text { Group } \\
\text { No. }\end{array}$ & Specimens & $\begin{array}{c}\text { First Crack } \\
\text { load (F.C.L) } \\
(\mathrm{kN})\end{array}$ & $\begin{array}{c}\text { Ultimate } \\
\text { load (U.L) } \\
(\mathrm{kN})\end{array}$ & $\begin{array}{c}\frac{F \cdot C \cdot L}{U . L} \\
(\%)\end{array}$ \\
\hline \multirow{2}{*}{1} & BC1 & 27.5 & 52.5 & 52.4 \\
& BC2 & 22.5 & 94.5 & 23.8 \\
& BC3 & 18.5 & 102.5 & 17.1 \\
& BP1 & 8 & 44 & 18.18
\end{tabular}




\begin{tabular}{ccccc}
2 & BP2 & 10 & 77.5 & 12.9 \\
& BP3 & 27.5 & 87.5 & 31.43 \\
& BP1. A & 9.5 & 51.5 & 18.45 \\
3 & BP2. A & 17.5 & 82.5 & 21.21 \\
& BP3. A & 20 & 96.5 & 20.73 \\
\hline
\end{tabular}

*. Both plasters of Paris and normal concrete have the same dimension $(1000 \times 150 \times 200) \mathrm{mm}$.

Entering the curing time effect in computed Load-Deflection curve can be observed that in (Fig. 4) as well as (Fig. 5) and (Fig. 6) all of them in increasing curing time the ultimate load increased with decreased in deflection but the (BP3.A, BC3) samples give the highest value of ultimate load:

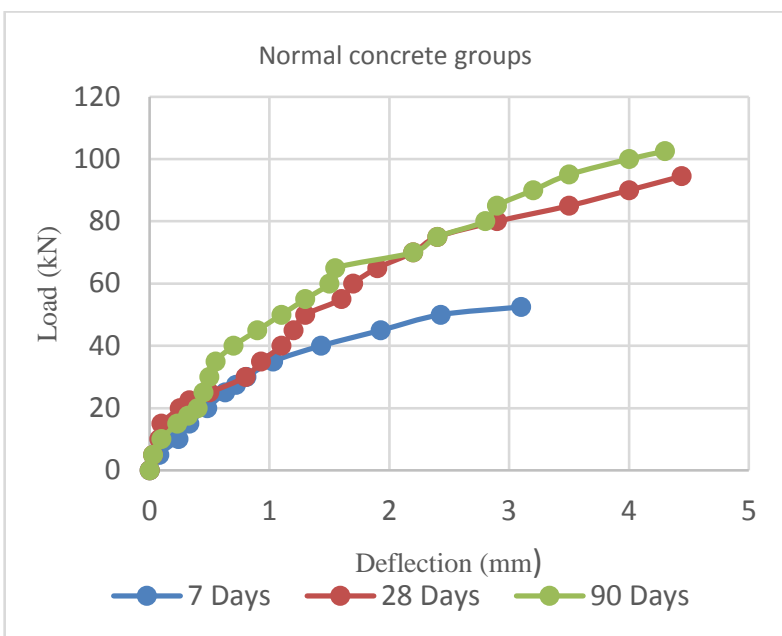

Fig. 4: Load - Deflection Curve of Specimen (BC)

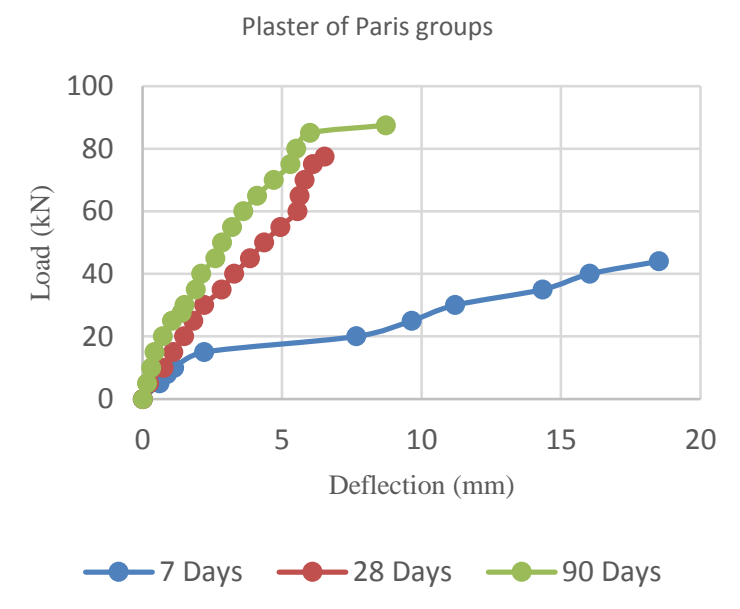

Fig. 5: Load - Deflection Curve of Specimen (BP)

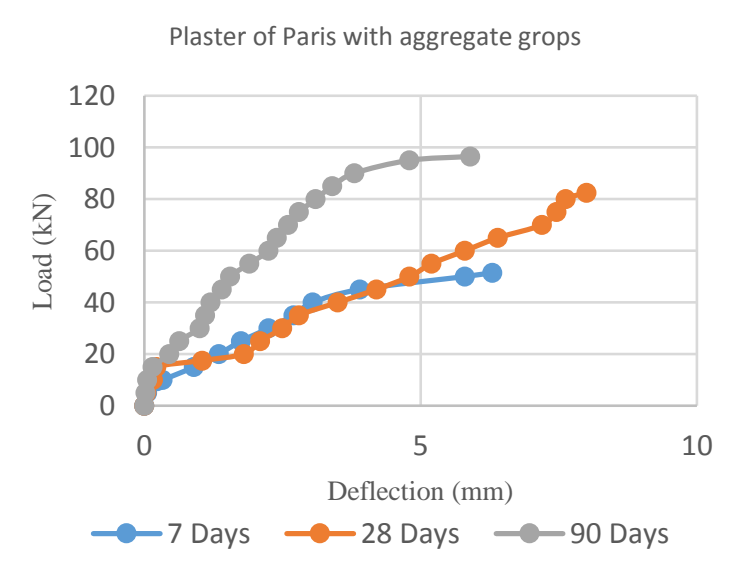

Fig. 6: Load - Deflection Curve of Specimen (BP. A)
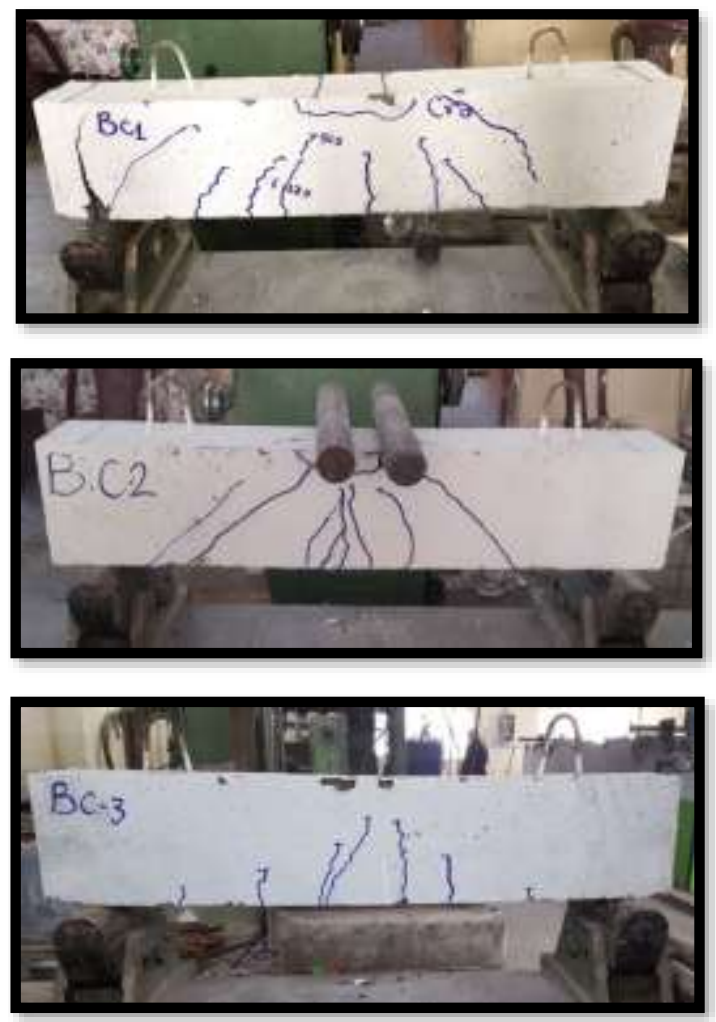

Fig. 7: Show the crack patterns and modes of failure of each beam of (BC) group
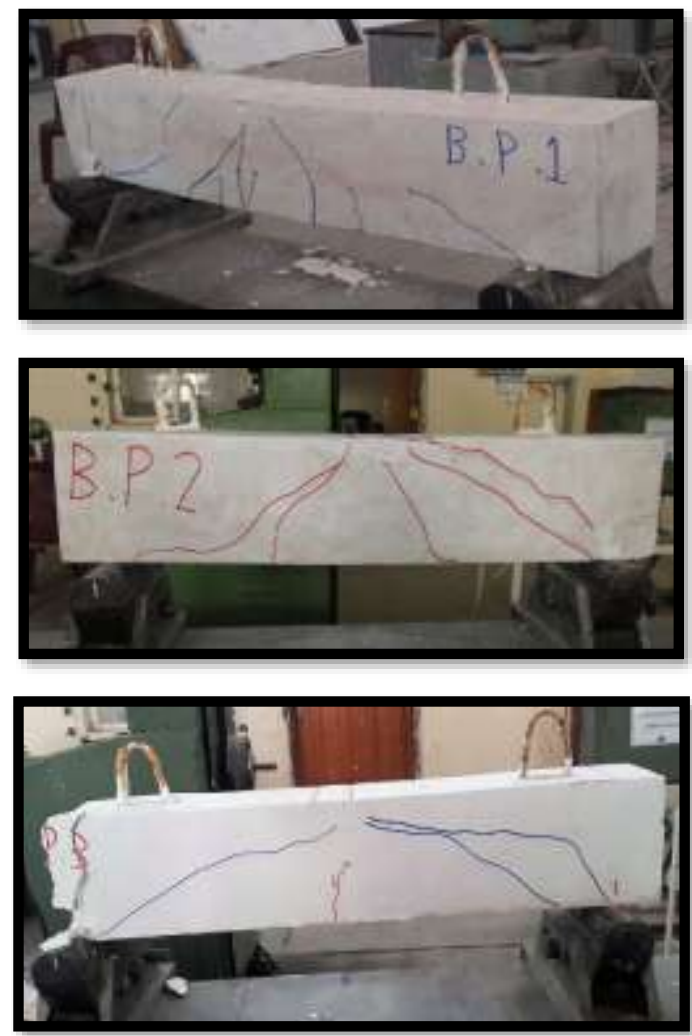

Fig. 8: Show the crack patterns and modes of failure of each beam of (BP) group 

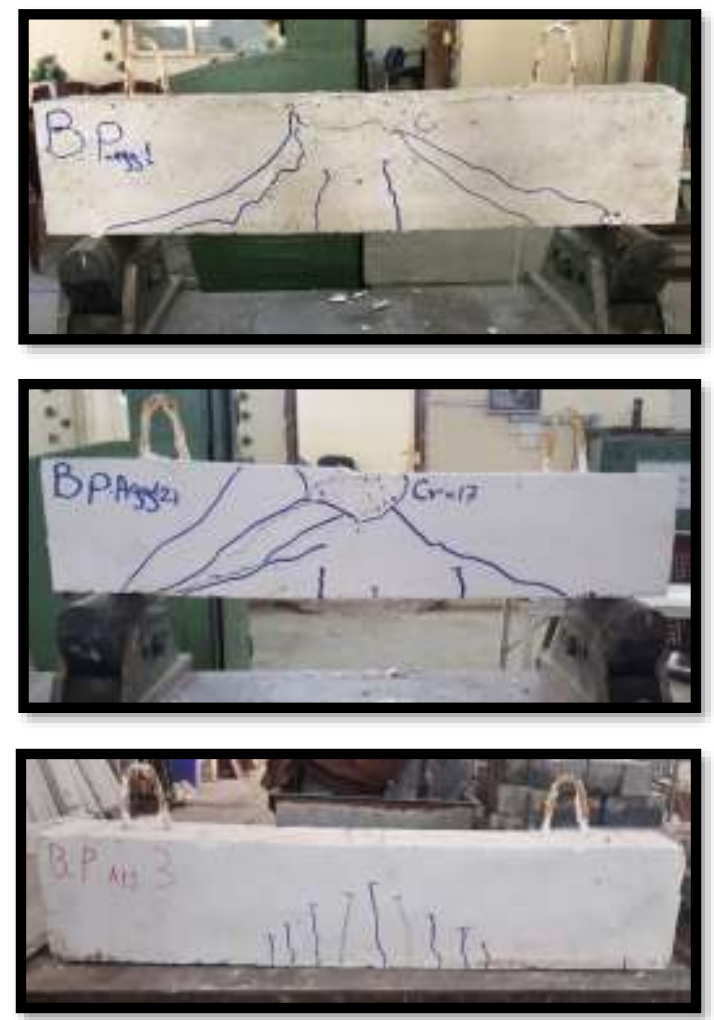

Fig. 9: Show the crack patterns and modes of failure of each beam of (BP. A) group

The hydraulic universal testing machine (MFL system) is used to test all beam specimens. The testing machine has three scale loads ( 0 to $600 \mathrm{kN}, 0$ to $1500 \mathrm{kN}, 0$ to $3000 \mathrm{kN}$ ). The machine is shown in "Fig. 8". The high capacity, stiffness, and dimensions of the testing machine make it more adequate to test different types of specimens. All the models were tested in the construction laboratory of Al-Mustansiriyah University College of Engineering.

\section{Conclusion}

The result appeared that normal concrete was still the best but when used the alternatives suggested in this research (Plaster of Paris with aggregate) give construction sufficient result where the percentage of convergence in two-point load test equal to (98\%) in seven days, $(87 \%)$ in twenty-eight days and $(94 \%)$ in ninety days ,as well as The material test in compressive strength give percent ratio of $(82.71 \%)$, in splitting test $(80.76 \%)$ and in modulus of rupture (89\%). While plaster of Pairs without aggregate give the lowest result in all test, that indicate adding aggregate make an improvement to the properties. with increasing curing time, the strength of samples to load increased with decreased in deflection.

\section{Acknowledgment}

The authors wish to acknowledge the construction laboratory of AlMustansiriyah University College of Engineering and Building Research Directorate - Ministry of Construction and Housing Municipalities and Public Works for their facilitation to complete this research by introducing help to examine the materials and samples.

\section{References}

[1] L. S. A.-K. Al-Ubaidi, "Improving Properties of Gypsum by Using Additive Materials " Master, Building and Construction Engineering University Of Technology 2004.

[2] "Fire shield wallboard" "www.national gypsum company, 2002, p.14.
[3] L. S. A.-K. Al-Ubaidi, "Improving Properties of Gypsum by Using Additive Materials " Master, Building and Construction Engineering University of Technology 2004.

[4] Hassan, Raed Khalis and Mulla, Ikram Faroon, "Improving the properties of plaster using additives", Diploma of Engineering in Quality Control of Building Materials, University of Technology, July 1999, pp.

[5] H. k. A. Obeidi, "Improving plaster properties using additives," MSc, Civil Engineering, Faculty of Engineering / University of Baghdad,

[6] ACI Committee 318 (2014),"Building Code Requirements for Structural Concrete and Commentary (ACI-318-14)", American Concrete Institute. Farmington Hills, MI, USA.

[7] ACI 211.1-91, "Standard Practice for Selecting Proportions for Normal, Heavyweight, and Mass Concrete, American Concrete Institute".

[8] ASTM C 317/C 317M - 00 "Standard Specification for Gypsum Concrete1", Vol. 04.01, p.1.

[9] ASTM C 956 - 04 "Standard Specification for Installation of CastIn-Place Reinforced Gypsum Concrete", p.2, 2004.

[10] B.S:1881: Part 116:1983 "Method for Determination of Compressive Strength Concrete Cube ", British standard institution, (1983).

[11] ASTMC39,"Standard Test Method for Compressive Strength of Cylindrical Concrete Specimens" p.5, 2001

[12] ASTM C496,"Standard Test Method for Splitting Tensile Strength of Cylindrical Concrete Specimens", p.5, 2004.

[13] ASTM C78,"Standard Test Method for Flexural Strength of Concrete (Using Simple Beam with Two Points Loading", Annual Book of ASTM Standard, Vol. 04, No.02, 2002. 